\title{
RELIGIOUS BELIEF AND ITS INFLUENCE ON HEALTHY AGEING AMONG THE ELDERLY IN BLORA, CENTRAL JAVA
}

\author{
Niena Ayu Cahyaningtyas'), Aris Sudiyanto'), RB. Soemanto3) \\ ${ }^{1)}$ Master Program in Public Health, Universitas Sebelas Maret \\ ${ }^{2)}$ Departement of Psychiatry, Faculty of Medicine, \\ Universitas Sebelas Maret \\ 3)Faculty of Social and Political Sciences, Universitas \\ Sebelas Maret
}

\begin{abstract}
Background: WHO defines healthy ageing "as the process of developing and maintaining the functional ability that enables wellbeing in older age". This study aimed to examine religious belief and its influence on healthy ageing among the elderly in Blora, Central Java.

Subject and Method: A cross-sectional study was conducted in Blora, Central Java. A sample of 200 older people was selected for this study by snowball sampling. The dependent variable was healthy ageing. The independent variables were nutrition intake, age, religious (spiritual) belief, education, and income. Data on healthy ageing was collected by WHOQOL-BREF. The other variables were measured by questionnaire. The data were analyzed by a multiple linear regression. Results: Healthy ageing was positively associated with strong spiritual belief $(\mathrm{b}=$ 6.57; $95 \% \mathrm{CI}=3.48$ to 9.66; $\mathrm{p}<0.001$ ), better education ( $\mathrm{b}=7.43 ; 95 \% \mathrm{CI}=3.69$ to $11.16 ; \mathrm{p}<0.001)$, higher income $(\mathrm{b}=6.77 ; 95 \% \mathrm{CI}=3.30$ to $10.23 ; \mathrm{p}<0.001)$, good nutritional status $(\mathrm{b}=7.00 ; 95 \% \mathrm{CI}=3.89$ to $10.11 ; \mathrm{p}<0.001)$, but was negatively associated with age $(b=-3.56 ; 95 \% \mathrm{CI}=-6.98$ to $-0.14 ; \mathrm{p}=0.041)$.

Conclusion: Healthy ageing is positively associated with strong spiritual belief, better education, higher income, good nutritional status, but is negatively associated with age.
\end{abstract}

Keywords: healthy ageing, religious belief, elderly, ageing

\section{Correspondence:}

Niena Ayu Cahyaningtyas. Masters Program in Public Health, Universitas Sebelas Maret, Jl Ir. Sutami 36A, Surakarta 57126, Central Java.

Email: niena.ayu21@gmail.com. Mobile: 085640776171

The 4th International Conference on Public Health

Best Western Premier Hotel, Solo, Indonesia, August 29-30, 2018 | 106 https://doi.org/10.26911/theicph.2018.01.67 